\title{
Possible involvement of Syndecan-1 in the state of COVID-19 related to endothelial injury
}

Keiko Suzuki ${ }^{1}$, Hideshi Okada ${ }^{2 *}$ D, Hiroyuki Tomita ${ }^{3}$, Kazuyuki Sumi ${ }^{1}$, Yoshinori Kakino², Ryu Yasuda ${ }^{2}$, Yuichiro Kitagawa², Tetsuya Fukuta², Takahito Miyake², Shozo Yoshida², Akio Suzuki ${ }^{2}$ and Shinji Ogura²

\begin{abstract}
Background: The coronavirus infection 2019 (COVID-19) is associated with microvascular endothelial injury. Here, we report that syndecan-1, a component of endothelial glycocalyx, may reflect the disease state of COVID-19 related to endothelial injury.

Case presentation: A patient with COVID-19 was transferred to the intensive care unit of our hospital. Computed tomography of the chest showed bilateral ground glass opacities, which was diagnosed as acute respiratory syndrome. The $\mathrm{PaO}_{2} / \mathrm{F}_{1} \mathrm{O}_{2}$ ratio gradually increased from 158 on hospitalization to 300 on Day 11 , on which day the ventilator was withdrawn. However, serum syndecan-1 (SDC-1) level gradually decreased from $400.5 \mathrm{ng} / \mathrm{ml}$ at hospitalization to $165.1 \mathrm{ng} / \mathrm{ml}$ on Day 5. On Day 6, serum SDC-1 level increased to $612.9 \mathrm{ng} / \mathrm{ml}$ owing to a systemic thrombosis with an increase in D-dimer. Serum SDC-1 level then decreased until $206.0 \mathrm{ng} / \mathrm{ml}$ on Day 11 after a decrease in D-dimer. The patient was transferred to another hospital on Day 21 after hospitalization.

Conclusions: In this case report, changes in serum SDC-1 level closely reflected the change in disease condition in a patient with COVID-19. Serum SDC-1 may be a useful biomarker for monitoring the disease state of critically ill patients with COVID-19.
\end{abstract}

Keywords: COVID-19, Syndecan-1, Endothelial glycocalyx, D-dimer

\section{Background}

Patients infected with the pandemic novel coronavirus (COVID-19) typically develop severe acute respiratory syndrome (ARDS). ARDS results from diffuse injury to cells that form the alveolar barrier, surfactant dysfunction, activation of innate immune response, and abnormal coagulation [1]. Recent reports have suggested that one of the mechanisms of ARDS induced by COVID-19 may be involved in microvascular endothelial cell injury [2]. Microvascular endothelial cell injury promotes

\footnotetext{
* Correspondence: hideshi@gifu-u.ac.jp

${ }^{2}$ Department of Emergency and Disaster Medicine, Gifu University Graduate School of Medicine, 1-1 Yanagido, Gifu 501-1194, Japan

Full list of author information is available at the end of the article
}

thrombosis, particularly in the alveolar capillaries of COVID19 pneumonia patients [3, 4]. The glycocalyx, a gel like substance that coats the luminal surface of endothelial cells, largely inhibits platelet adhesion to the microvasculature [2]. Inflammation-induced degradation of the glycocalyx, which is measured by the glycocalyx biomarkers syndecan-1 (SDC-1), sP-selectin and hyaluronic acid, contribute to microvascular pathology in COVID19 patients [5, 6]. Recently, the protection and restoration of glycocalyx has been suggested to be a key therapeutic target for COVID-19 [2, 5].

Here, we present the case of a COVID-19 patient with ARDS in whom serum SDC-1, a component of glycocalyx, was measured over time, and examine the 
association of SDC-1 as a reflection of the disease state of COVID-19 in relation to endothelial injury.

\section{Case presentation}

The patient was a 63-year-old male with no medical history. He developed a $38^{\circ} \mathrm{C}$ fever and visited his local general hospital. Reverse transcription polymerase chain reaction (RT-PCR) testing for severe acute respiratory syndrome coronavirus (SARS-CoV-2) nucleic acid in nasopharyngeal swabs was negative. The fever had not resolved 6 days after his initial symptoms and he visited the hospital again. Computed tomography (CT) of the chest showed bilateral ground glass opacities, and oxygen saturation $\left(\mathrm{SpO}_{2}\right)$ under room conditions was $85 \%$. Loop-Mediated isothermal amplification (LAMP) assay for SARS-CoV-2 nucleic acid in nasopharyngeal swabs was positive. On the same day, the patient was intubated and administered remdesivir (200 mg SID on Day 1, then $100 \mathrm{mg}$ SID; d.i.v.), dexamethasone (6.6 mg SID; d.i.v.) and heparin sodium (10,000 units; d.i.v.). At 8 days after the initial symptoms, he was transferred to our hospital due to worsening respiratory status.

Laboratory test findings on admission to the intensive care unit (ICU) of our hospital were serum albumin, 2.4 $\mathrm{g} / \mathrm{dl}$; serum aspartate transaminase, $27 \mathrm{U} / \mathrm{l}$; serum alanine aminotransferase, $27 \mathrm{U} / \mathrm{l}$; serum creatinine, 0.74 $\mathrm{mg} / \mathrm{dl}$; serum creatine kinase, $33 \mathrm{U} / \mathrm{l}$; white blood cells, $14.67 \times 10^{3} / \mu \mathrm{l}$; serum hemoglobin, $13.7 \mathrm{~g} / \mathrm{dl}$; platelets, $247 \times 10^{3} / \mu \mathrm{l}$; serum D-dimer, $2.4 \mu \mathrm{g} / \mathrm{ml}$; and serum fibrinogen degradation products, $535 \mathrm{mg} / \mathrm{dl}$. Arterial blood gas analysis on 0.6 fraction of inspired oxygen $\left(\mathrm{F}_{\mathrm{I}} \mathrm{O}_{2}\right)$ revealed a $\mathrm{pH}$ of 7.373 , partial pressure of oxygen $\left(\mathrm{PaO}_{2}\right)$ of $134 \mathrm{mmHg}$, partial pressure of carbon dioxide $\left(\mathrm{PaCO}_{2}\right)$ of $34.9 \mathrm{mmHg}$, bicarbonate $\left(\mathrm{HCO}_{3}{ }^{-}\right)$of 19.8 $\mathrm{mmol} / \mathrm{l}$, base excess of $-4.3 \mathrm{mmol} / \mathrm{l}$, and lactate of 10 $\mathrm{mg} / \mathrm{dl}$ [Respirator mode: synchronous intermittent mandatory ventilation (SIMV), positive end-expiratory pressure (PEEP): $12 \mathrm{cmH}_{2} \mathrm{O}$ ]. $\mathrm{CT}$ of the chest showed bilateral ground glass opacities (Fig. 1a, red arrowhead), which was diagnosed as ARDS. Remdesivir (100 mg SID; d.i.v.) and dexamethasone (6.6 mg SID; d.i.v.) were continued, and nafamostat mesilate $(6.25 \mathrm{mg} / \mathrm{hr}$; d.i.v. $)$ and ampicillin/sulbactam (3 g q6hr; d.i.v.) were started. Serum syndecan-1 level, which was measured using an enzyme-linked immunosorbent assay (950.640.192; Diaclone, Besancon, Cedex, France), was $400.5 \mathrm{ng} / \mathrm{ml}$ (Fig. 2).

$\mathrm{PaO}_{2} / \mathrm{F}_{\mathrm{I}} \mathrm{O}_{2}$ ratio gradually increased from the day after hospitalization, reaching 166 on Day 2, 173 on Day 3, 223 on Day 4 and 179 on Day 5. Similarly, serum SDC-1 level gradually decreased from day after hospitalization, reaching 244.6 on Day 2, 168.5 on Day 3, 194.0 on Day 4 and $165.1 \mathrm{ng} / \mathrm{ml}$ on Day 5 . His dexamethasone dose was reduced to $3.3 \mathrm{mg}$ on Day 6 (Fig. 2).

However, a daily increase in D-dimer was observed from the day after hospitalization, which was considered due to systemic thrombosis following endothelial cell injury by SARS-CoV-2. We re-administrated heparin sodium (15,000 units; d.i.v.) from Day 5. Levels peaked on Day 6 and gradually decreased thereafter (Fig. 2). Serum SDC-1 levels also increased again on Day 6 to $612.9 \mathrm{ng} / \mathrm{ml}$, remained high until Day 8, then reduced after the decrease in D-dimer. On Day 7, nafamostat mesilate was discontinued. On Day 8, improvement in bilateral infiltrates was observed on chest X-ray (data not shown), and dexamethasone was discontinued. On Day 9, LAMP assay for SARS$\mathrm{CoV}-2$ nucleic acid in nasopharyngeal swabs was positive. On day 11, the patient was taken of the ventilator and switched to a high-flow nasal cannula because it was considered that the patient was not propagating SARS-CoV-2. Serum SDC-1 level at this time was decreased to $206.0 \mathrm{ng} / \mathrm{ml}$.

Thereafter, although his $\mathrm{PaO}_{2} / \mathrm{F}_{\mathrm{I}} \mathrm{O} 2$ ratio was temporarily decreased due to aspiration pneumonia and Creactive protein and white blood cells were increased (Fig. 2), the patient improved with antibiotic treatment. Serum SDC-1 level increased to $533.6 \mathrm{ng} / \mathrm{ml}$ during treatment for aspiration pneumonia.

On Day 15, LAMP assay for SARS-CoV-2 nucleic acid in nasopharyngeal swabs was positive. CT of the chest on Day 15 showed an improvement of bilateral ground
(A) On admission of intensive care unit

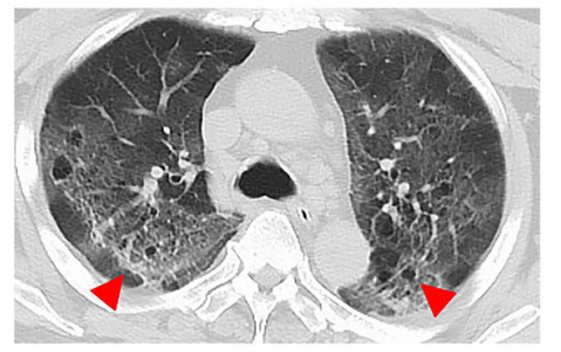

(B) Day 15 after hospitalizaiton

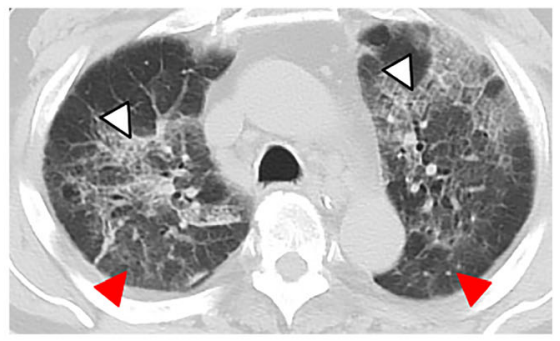

Fig. 1 Computed tomography (CT) scan of the chest on admission to the intensive care unit (a) and on Day 15 after admission (b) 


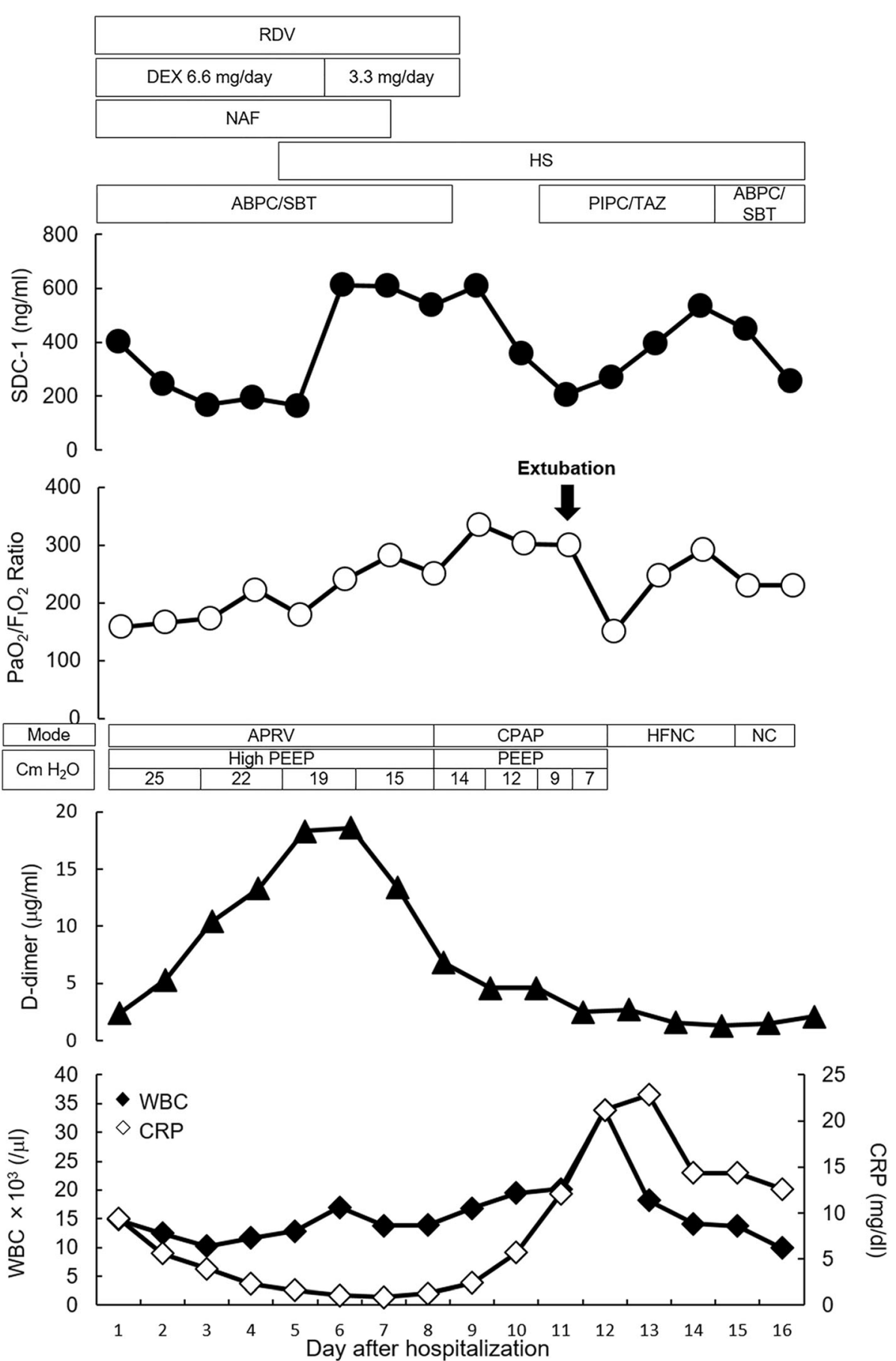

Fig. 2 Time course of serum syndecan-1, respiratory function, and changes in levels of inflammatory and coagulation markers. RDV: Remdesivir, DEX: Dexamethasone, NAF: Nafamostat mesilate, HS: Heparin sodium, ABPC/SBT: Ampicillin/Sulbactam, PIPC/TAZ: Piperacillin/Tazobactam, APRV: Airway pressure release ventilation, CPAP: Continuous positive airway pressure, HNC: High nasal cannula, NC: Nasal cannula, PEEP: Positive endexpiratory pressure, SDC-1: Syndecan-1, $\mathrm{PaO}_{2} / \mathrm{F}_{1} \mathrm{O}_{2}$ : Partial pressure of oxygen/Fraction of inspired oxygen, FDP: Fibrin degradation product, WBC: White blood cell, CRP: C-reactive protein

glass opacities compared with at hospitalization (Fig. 1b, red arrowhead), but other signs of pneumonia were seen (Fig. 1b, white arrowhead). The patient was transferred to another hospital on Day 21 after hospitalization.

\section{Discussion and conclusions}

SDC-1, heparan sulfate proteoglycan, is a core protein of the glycocalyx whose degradation indicates endothelial injury [7-9]. Two recent studies reported serum SDC-1 
levels in critically ill patients with COVID-19 [5,10]. Fraser et al. showed that critically ill patients with COVID19 had higher serum SDC-1, in addition to sP-selectin and hyaluronic acid, particularly on Day 3 after admission to the ICU and thereafter [5]. Conversely, Hutchings et al. reported that serum SDC-1 levels were mildly elevated in critically ill patients with COVID-19 compared to healthy controls, and that only a very small number of patients had evidence of marked glycocalyx shedding [10]. Therefore, the relationship between treatment progress and serum SDC-1 level in critically ill patients with COVID-19 has remained controversial. In this case report, we evaluated the time course of serum SDC-1 concentration in a patients with COVID-19 from admission to the ICU to the time his respiratory condition improved.

On admission to our hospital, CT of the chest showed bilateral ground glass opacities of the ARDS phenotype and serum SDC-1 level was $400.5 \mathrm{ng} / \mathrm{ml}$. Our previous study in 78 healthy individuals receiving no treatment and with no relevant medical history or laboratory data reported a median serum SDC-1 concentration of 19.3 $\mathrm{ng} / \mathrm{ml}$ [11]. Therefore, the initial serum SDC-1 level was very high in the present case, consistent with previous reports $[5,10]$. Importantly, his serum SDC-1 level gradually decreased with improvement in respiratory condition, as evaluated by $\mathrm{PaO}_{2} / \mathrm{F}_{\mathrm{I}} \mathrm{O}_{2}$ ratio.

In contrast, D-dimer gradually increased after hospitalization, indicating a coagulation disorder associated with COVID-19 [2]. The addition to heparin sodium was effective, and his D-dimer level peaked 6 days later. The serum SDC-1 level increased again in response to this endothelial injury due to COVID-19associated thrombosis. Moreover, after the decrease in D-dimer, serum SDC-1 also decreased. These findings suggest that serum SDC-1 may well reflect endothelial injury associated with COVID-19.

The present patient developed aspiration pneumonia after removal of the respirator, and an increase in serum SDC-1 level was again observed. Smart et al. reported that SDC-1 and hyaluronan, a component of the glycocalyx, are significantly increased over time in patients with sepsis due to pneumonia, which is consistent with our present case [12].

The precise mechanism of shedding of SDC-1 from glycocalyx by SARS-CoV-2 is still unknown. However, Fraser et al. suggested that granzyme B and elastase 2, which are serine proteases, are elevated in ICU patients with COVID-19 relative to ICU patients without COVID-19 [13]. Elevated granzyme B and elastase 2 has been demonstrated under severe inflammatory conditions and contributes to the endothelial injury $[14,15]$. Thus, these serine proteases may contribute to the degradation of glycocalyx. Indeed, several studies have reported that nafamostat, a serine protease inhibitor, is effective against COVID-19 [16, 17]. On the other hand, SDC-1 is also expressed in other organs, in addition to endothelial glycocalyx. Additionally, it is important to note that the usefulness of D-dimer in the management of patients with COVID-19 remains uncertain [18]. Moreover, we report here only a single case, yet several mutations in SARS-CoV-2 have been reported, in which the pathogenicity of the virus may differ [19]. To verify the accuracy of the change in serum SDC-1 level in COVID-19 patients, further large-scale studies are warranted.

\section{Abbreviations \\ COVID-19: Coronavirus infection 2019; ARDS: Acute respiratory syndrome; SDC-1: Syndecan-1; RT-PCR: Reverse transcription polymerase chain reaction; SARS-CoV-2: Severe acute respiratory syndrome coronavirus; CT: Computed tomography; $\mathrm{SpO}_{2}$ : Oxygen saturation; LAMP: Loop-Mediated isothermal amplification; ICU: Intensive care unit; $\mathrm{PaO}_{2}$ : Partial pressure of oxygen; $\mathrm{PaCO}_{2}$ : Partial pressure of carbon dioxide; $\mathrm{HCO}_{3}$ : Bicarbonate; SIMV: Synchronous intermittent mandatory ventilation; PEEP: Positive end- expiratory pressure}

\section{Acknowledgements}

The authors would like to thank the paramedical crews for the data.

\section{Authors' contributions}

$\mathrm{HO}$, YK, RY, YK, TF, TM, SY and SO treated the patient. Keiko $S$ and Kazuyuki S measured SDC-1 using ELISA. Keiko S, HO, HT and AS wrote the manuscript. $\mathrm{HO}$ revised and edited. The author(s) read and approved the final manuscript.

\section{Funding}

None.

\section{Availability of data and materials}

The datasets obtained and analyzed in the current study are available from the corresponding author on reasonable request.

\section{Ethics approval and consent to participate}

In Japan, a case report does not require ethics approval. Our study adhered to the Ethical Guidelines for Medical and Health Research Involving Human Subjects established by the government of Japan.

\section{Consent for publication}

Written informed consent was obtained from the patient's legal guardians for publication of this case report and any accompanying images. A copy of the written consent is available for review by the Editor-in-Chief of this journal.

\section{Competing interests}

The authors declare that they have no competing interests.

\section{Author details}

${ }^{1}$ Department of Pharmacy, Gifu University Hospital, Gifu, Japan. ${ }^{2}$ Department of Emergency and Disaster Medicine, Gifu University Graduate School of Medicine, 1-1 Yanagido, Gifu 501-1194, Japan. ${ }^{3}$ Department of Tumor Pathology, Gifu University Graduate School of Medicine, Gifu, Japan.

Received: 6 November 2020 Accepted: 13 January 2021

Published online: 27 January 2021

\section{References}

1. Matthay MA. Acute respiratory distress syndrome. Nat Rev Dis Primers. 2019; 5(1):18.

2. Okada H, Yoshida S, Hara A, Ogura S, Tomita H. Vascular endothelial injury exacerbates coronavirus disease 2019: The role of endothelial glycocalyx 
protection. Crit Care Explor. 2020;2(10):e0272. https://doi.org/10.1097/CCE. 0000000000000272.

3. Chang JC. Sepsis and septic shock: endothelial molecular pathogenesis associated with vascular microthrombotic disease. 2019:17:10.

4. Magro C, Mulvey JJ, Berlin D, Nuovo G, Salvatore S, Harp J, Baxter-Stoltzfus A, Laurence J. Complement associated microvascular injury and thrombosis in the pathogenesis of severe COVID-19 infection: a report of five cases. Trans Res. 2020;220:1-13. https://doi.org/10.1016/j.trsl.2020.04.007.

5. Fraser DD, Patterson EK, Slessarev M, Gill SE, Martin C, Daley M, Miller MR, Patel MA, Dos Santos CC, Bosma KJ, O'Gorman DB, Cepinskas G. Endothelial injury and Glycocalyx degradation in critically ill coronavirus disease 2019 patients: implications for microvascular platelet aggregation. Crit Care Explor. 2020;2(9):e0194. https://doi.org/10.1097/CCE.0000000000000194.

6. Stahl K, Gronski PA, Kiyan Y, Seeliger B, Bertram A, Pape T, Welte T, Hoeper MM, Haller H, David S. Injury to the endothelial Glycocalyx in critically ill COVID-19 patients. Am J Respir Crit Care Med. 2020; in press.

7. Rehm M, Bruegger D, Christ F, Conzen P, Thiel M, Jacob M, Chappell D, Stoeckelhubar M, Welsch U, Reichart B, et al. Shedding of the endothelial glycocalyx in patients undergoing major vascular surgery with global and regional ischemia. Circulation. 2007;116:1896-906.

8. Arthur A, McCall PJ, Jolly L, Kinsella J, Kirk A, Shelley BG. Endothelial glycocalyx layer shedding following lung resection. Biomark Med. 2016;10: 1033-8

9. Murphy LS, Wickersham N, McNeil JB, Shaver CM, May AK, Bastarache JA Ware LB. Endothelial glycocalyx degradation is more severe in patients with non-pulmonary sepsis compared to pulmonary sepsis and associates with risk of ARDS and other organ dysfunction. Ann Intensiv Care. 2017;7:102.

10. Hutchings SD, Watchorn J, Trovato F, Napoli S, Mujib SF, Hopkins P, McPhail M. Microcirculatory, endothelial and inflammatory responses in critically ill patients with COVID-19 are distinct from those seen in septic shock: a case control study. Shock. 2020. https://doi.org/10.1097/SHK.0000000000001672.

11. Oda K, Okada H, Suzuki A, Tomita H, Kobayashi R, Sumi K, Suzuki K, Takada C, Ishihara T, Suzuki K, Kano S, Kondo K, Iwashita Y, Yano H, Zaikokuji R, Sampei S, Fukuta T, Kitagawa Y, Okamoto H, Watanabe T, Kawaguchi T, Kojima T, Deguchi F, Miyazaki N, Yamada N, Doi T, Yoshida T, Ushikoshi H, Yoshida S, Takemura G, Ogura S. Factors enhancing serum Syndecan-1 concentrations: a large-scale comprehensive medical examination. J Clin Med. 2009;8(9):1320

12. Smart L, Bosio E, Macdonald SPJ, Dull R, Fatovich DM, Neil C, Arendts G Glycocalyx biomarker syndecan-1 is a stronger predictor of respiratory failure in patients with sepsis due to pneumonia, compared to endocan. J Crit Care. 2018:47:93-8.

13. Fraser DD, Cepinskas G, Slessarev M, Martin C, Daley M, Miller MR, O'Gorman DB, Gill SE, Patterson EK, Dos Santos CC. Inflammation profiling of critically ill coronavirus disease 2019 patients. Crit Care Explor. 2020;2(6):e0144.

14. Omoto Y, Yamanaka K, Tokime K, et al. Granzyme B is a novel interleukin-18 converting enzyme. J Dermatol Sci. 2010;59:129-35.

15. Suzuki K, Okada H, Takemura G, Takada C, Kuroda A, Yano H, Zaikokuji R, Morishita K, Tomita H, Oda K, Matsuo S, Uchida A, Fukuta T, Sampei S, Miyazaki N, Kawaguchi T, Watanabe T, Yoshida T, Ushikoshi H, Yoshida S, Maekawa Y, Ogura S. Neutrophil Elastase damages the pulmonary endothelial Glycocalyx in lipopolysaccharide-induced experimental Endotoxemia. Am J Pathol. 2019;189(8):1526-35.

16. Doi K, Ikeda M, Hayase N, Moriya K, Morimura N. Nafamostat mesylate treatment in combination with favipiravir for patients critically ill with Covid-19: a case series. Crit Care. 2020;24(1):392.

17. Jang S, Rhee JY. Three cases of treatment with nafamostat in elderly patients with COVID-19 pneumonia who need oxygen therapy. Int J Infect Dis. 2020;96:500-2

18. Hardy M, Lecompte T, Douxfils J, Lessire S, Dogné JM, Chatelain B, Testa S, Gouin-Thibault I, Gruel Y, Medcalf RL, Ten Cate H, Lippi G, Mullier F. Management of the thrombotic risk associated with COVID-19: guidance for the hemostasis laboratory. Thromb J. 2020;18:17.

19. Zhang L, Jackson CB, Mou H, Ojha A, Peng H, Quinlan BD, Rangarajan ES, Pan A, Vanderheiden A, Suthar MS, Li W, Izard T, Rader C, Farzan M, Choe H. SARS-CoV-2 spike-protein D614G mutation increases virion spike density and infectivity. Nat Commun. 2020;11(1):6013.

\section{Publisher's Note}

Springer Nature remains neutral with regard to jurisdictional claims in published maps and institutional affiliations.

Ready to submit your research? Choose BMC and benefit from:

- fast, convenient online submission

- thorough peer review by experienced researchers in your field

- rapid publication on acceptance

- support for research data, including large and complex data types

- gold Open Access which fosters wider collaboration and increased citations

- maximum visibility for your research: over $100 \mathrm{M}$ website views per year

At $\mathrm{BMC}$, research is always in progress.

Learn more biomedcentral.com/submissions 